DOI: $\square$ https://doi.org/10.15407/techned2020.03.069

\title{
PROGRESS OF SEMICONDUCTOR DISCHARGE-PULSE SYSTEMS FOR PROCESSING GRANULAR CONDUCTIVE MEDIA
}

Journal

Publisher

ISSN

Issue

Pages
Tekhnichna elektrodynamika

Institute of Electrodynamics National Academy of Science of Ukraine 1607-7970 (print), 2218-1903 (online)

No 3, 2020 (May/June)

$69-78$

\section{Authors \\ N.A. Shydlovska*, S.M. Zakharchenko** \\ Institute of Electrodynamics National Academy of Sciences of Ukraine, pr. Peremohy, 56, Kyiv, 03057, Ukraine, e-mail: shydlovska@ied.org.ua, snzakhar@ukr.net \\ * ORCID ID : https://orcid.org/0000-0002-9907-7416 \\ ** ORCID ID : https://orcid.org/0000-0002-8597-8045}

\begin{abstract}
An analysis of the evolution of semiconductor discharge-pulse systems for processing granular conductive media is given. The main types of thyristor generators of discharge pulses, the features of their operation, advantages and disadvantages are described. The methods of increasing the stability of parameters and reducing the duration of the discharge pulses of thyristor generators are analyzed. The ways of increasing the specific fraction of nanodispersed and submicron erosion particles obtained using thyristor discharge-pulse systems are shown. The development of transistor discharge pulse generators is described and their advantages and disadvantages are given. Algorithms for controlling transistor pulse generators, which make it possible to reduce their instability and a circuit of such generator are given. The ways of increasing the technical and economic indicators of transistor pulse generators are shown. Refe rences 36, figures 2 .
\end{abstract}

Key words: discharge-pulse systems, thyristor generators, transistor generators, spark and plasma erosion treatment, granular conductive media 
Received: 21.02.2020

Accepted: 17.04 .2020

Published: 05.05.2020

\section{References}

1. Asanov U.A., Tsoj A.D., Shcherba A.A., Kazekin V.I. Electroerosive technology of interconnections and powders of metals. Frunze: Ilym, 1990. 256 p. (Rus)

2. Perekos A.E., Chernenko V.A., Bunayev S.A., Zalutskiy V.P., Ruzhitskaya T.V., Boitsov O.F., Kakazei G.N. Structure and Magnetic Properties of Highly Dispersed Ni-Mn-Ga Powders Prepared by Spark-erosion. Journal of Applied Physics. 2012. Vol. 112. Pp. 093909-1 093909-7. DOI:

https://dx.doi.org/10.10

$63 / 1.4764017$

3. Nguyen P.K., Lee K.H., Kim S.I., Ahn K.A., Chen L.H., Lee S.M., Chen R.K., Jin S., Berkowitz A.E. Spark erosion: a high production rate method for producing Bi0.5Sb1.5Te3 nanoparticles with enhanced thermoelectric performance. Nanotechnology. 2012. Vol. 23. P. 415604-1 - 415604-7. DOI:

https://doi.org/10.1088/0957-4484/23/41/415604

4. Hong J.I., Parker F.T., Solomon V.C., Madras P., Smith D.J., Berkowitz A.E. Fabrication of spherical particles with mixed amorphous/crystalline nanostructured cores and insulating oxide shells. J. Mater. Res. 2008. Vol. 23. Issue 06. P. 1758-1763. DOI: https://doi.org/10.1557/JM R.2008.0199

5. Solomon V.C., McCartney M., Tang Y.J., Berkowitz A.E., O'Handley R.C., Smith D.J. Magnetic domain configurations in spark-eroded ferromagnetic shape memory Ni-Mn-Ga particles. Appl. Phys. Lett. 2005. Vol. 86. P. 192503-1 - 192503-3. DOI: https://doi.org/10.106 3/1.1925319

6. Liu Y., Zhu K., Li X., Lin F., Li Y. Analysis of multi-scale Ni particles generated by ultrasonic aided electrical discharge erosion in pure water. Advanced Powder Technology. 2018. Vol. 29. Issue 4. Pp. 863-873. DOI:

https://doi.org/10.1016/j.apt.2018.01.003

7. Berkowitz A.E., Hansen M.F., Parker F.T., Vecchio K.S., Spada F.E., Lavernia E.J., Rodriguez R. Amorphous soft magnetic particles produced by spark erosion. Journal of Magnetism and Magnetic Materials

. 2003. Vol. 254-255. Pp. 1-6. DOI:

https://doi.org/10.1016/S0304-8853(02)00932-0

8. Dvornik M.I. Nanostructured WC-Co particles produced by carbonization of spark eroded powder: Synthesis and characterization. Int. Journal of Refractory Metals \& Hard Materials. 2010. Vol. 28. Issue 4. Pp. 523-528. DOI:

https://doi.org/10.1016/j.ijrmhm.2010.02.011 
9. Monastyrsky G.E., Yakovenko P.A., Kolomytsev V.I., Koval Yu.N., Shcherba A.A., Portier R. Characterization of spark-eroded shape memory alloy powders obtained in cryogenic liquids. $M$ aterials Science and Engineering: $A$

. 2008. Vol. 481-482. Pp. 643-646. DOI:

https://doi.org/10.1016/j.msea.2006.12.213

10. Danilenko N.B., Savelev G.G., Yavorovskii N.A., Khaskel'berg M.B., Yurmazova T.A., Shamanskii V.V. Water purification to remove As(V) by electropulse treatment of an active metallic charge. Russian Journal of Applied Chemistry. 2005. Vol. 78. No 10. Pp. 1631-1635. D Ol:

https://doi.org/10.1007/s11167-005-0575-6

11. Danilenko N.B., Galanov A.I., Kornev Ya.I., Balukhtin P.V., Shyian L.N., Yurmazova T.A., Yavorovskii N.A., Savelev G.G. Application of pulsing electric discharges in aqueous solutions for production of nano-size materials and their use for water purification. Nanotekhnika. 2006. No 4(8). Pp. 81-90. (Rus)

12. Kornev la., Saprykin F., Lobanova G., Ushakov V., Preis S. Spark erosion in a metal spheres bed: Experimental study of the discharge stability and energy efficiency. Journal of Electrostatics

2018. Vol. 96. Pp. 111-118. DOI:

https://doi.org/10.1016/j.elstat.2018.10.008

13. Shcherba A.A., Zakharchenko S.N., Lopatko K.G., Aftandilyants E.G. Application of volume electric spark dispersion for production steady to sedimentation hydrosols of biological active metals. Pratsi Instytutu Elektrodynamiky Natsionalnoi Akademii Nauk Ukrainy. 2009. Issue 22. Pp. 74-79. (Rus)

14. Lopatko K.G., Melnichuk M.D. Physics, synthesis and biological functionality of nanosize objects. Kyiv: Vidavnichij centr Natsionalnogo Universitetu Bioresursiv i Priridokoristuvannya Ukraini, 2013. 297 p. (Ukr)

15. Borisevich V.B., Kaplunenko V.G., Kosinov N.V., Borisevich B.V. and all. Nanomaterials and nanotechnology in veterinary practice. Kyiv: Avitsena, 2012. 512 p. (Rus)

16. Shcherba A.A. Installation of electroerosive dispersion of conductive materials. Tekhniches kaya Elektrodinamika

1990. No 3. Pp. 88-92. (Rus)

17. Shcherba A.A. Thyristor power supply systems of technological plants with parametric stabilization of output characteristics. Sbornik nauchnykh trudov Preobrazovaniye i stabilizatsiya parametrov elektricheskoy energii

elektrodimamiki Natsionalnoy Akademii nauk Ukrainy, 1996. P. 18-27. (Rus)

18. Shcherba A.A., Zakharchenko S.N., Shevchenko N.I., Suprunovskaya N.I. Thyristor Discharge Pulse Generator with Controllable Parameters for Thechnological System for Volumetric Electric Spark Dispersion of Metal Granules. Tekhnichna Elektrodynamika. Tematychnyi vypusk Sylova elektronika ta enerhoefektyvnist. 2005. Part 1. Pp. 57-60.

19. Shcherba A.A. Principles of construction and stabilization of parameters of semi-conductor electro-pulse systems for electro-spark dispersion of current-conducting materials layer. Sbornik nauchnykh trudov. Stabilizatsiia parametrov elektricheskoi energii

. Kiev: Institut elektrodimamiki Akademii nauk Ukrainy, 1991. Pp. 12 - 30. (Rus)

20. Shcherba A.A. The basic principles of the construction of multiphase stabilized power supplies for installations of electroerosive dispersion of metals in liquids. III-rd All-Union Conference Problemy preobrazovatelnoy tekhniki 
. Kiev, Ukraine, 1983. Part 5. Pp. 59-62. (Rus)

21. Zakharchenko S.N. Features of electromagnetic processes in the installations of spark erosion coagulation for water treatment systems of heat networks and units. Novyny Enerhetyky . 2012. No 6. Pp. 41-48. (Rus)

22. Zakharchenko S.M. Statistical Research of Equivalent Electric Resistance of the Heterogeneous Current-carrying Medium at its Electroerosive Processing on an Example of Granules of Aluminum in Water. Naukovyi Visnyk Natsionalnoho hirnychoho universytetu. 2013. No 1 (133). Pp. 62-67. (Ukr)

23. Shcherba A.A., Suprunovska N.I., Ivashchenko D.S. Determination of Probabilistic Properties of Electrical Characteristics of Circuits of Electric Discharge Installations taking into Account their Stochastically Changing Parameters. Tekhnichna Elektrodynamika. 2019. No 4. Pp. 3-11. (Rus) DOI:

https://doi.org/10.15407/techned2019.04.003

24. Shydlovskaya N.A., Zakharchenko S.N., Cherkasskyi A.P. Nonlinear-parametrical Model of Electrical Resistance of Current-Carrying Granulated Mediums for a Wide Range of Applied Voltage. Tekhnichna Elektrodynamika. 2014. No 6. Pp. 3-17. (Rus)

25. Shcherba A.A., Suprunovska N.I., Ivashchenko D.S. Modeling of Nonlinear Resistance of Electro-spark Load for Synthesis of Discharge Circuit of Capacitor by Time Parameters. Tekhni chna Elektrodynamika

. 2014. No 3. Pp. 12-18. (Rus)

26. Shydlovska N.A., Zakharchenko S.M., Cherkaskyi O.P. Parametric Model of

Plasma-erosive Load, Adequate in the Wide Range of Change of Applied Voltage. Tekhnichna Elektrodynamika

. 2017. No 3. Pp. 3-12. (Ukr) DOI:

https://doi.org/10.15407/techned2017.03.003

27. Shcherba A.A., Zakharchenko S.N., Suprunovskaya N.I., Shevchenko N.I. The influence of repetition rate of discharge pulses on electrical resistance of current-conducting granular layer during its electric-spark treatment. Tekhnichna Elektrodynamika. 2006. No 2. Pp. 10-14.

28. Zakharchenko S.M. Increase of Efficiency of Obtaining of Ultradispersive Metals Particles by Volume Electroerosive Dispersion their Granules in a Liquid. Tekhnichna Elektrodynamika. 2013. No 1. Pp. 16-23. (Rus)

29. Shidlovskii A.K., Suprunovskaya N.I. Energy processes in the electrical circuits of discharge-pulse installations with a capacitive energy storage device while limiting the duration of its discharge to the spark load and non-zero initial conditions. Tekhnichna Elektrodynamika. 2010. No 1. Pp. 42-48. (Rus)

30. Shcherba A.A., Suprunovska N.I., Shcherba M.A. Transient Analysis in Circuits of Electric Discharge Installations with Voltage Feedback taking into Account the Recovery Time of Locking Properties their Semiconductor Switches. Tekhnichna Elektrodynamika. 2018. No 3. Pp. 43-47. DOI:

https://doi.org/10.15407/techned2018.03.043

31. Rudenko V.S, Senko V.I, Chizhenko I.M. Conversion techniques. Kyiv: Vyshcha shkola, 1983. 431 p. (Rus)

32. Livshitz A.L., Otto M.Sh. Pulse Electrical Engineering. Moskva: Energoatomizdat, 1983. 352 p. (Rus)

33. Zakharchenko S.N., Kondratenko I.P., Perekos A.E., Zalutsky V.P., Kozyrsky V.V., Lopatko K.G. Influence of discharge pulses duration in a layer of iron granules on the size and 
structurally-phase conditions of its electroerosion particles. Eastern-European Journal of Enterprise Technologies . 2012. Vol.

6. No 5 (60). Pp. 66-72. (Rus)

34. Shcherba A.A., Zakharchenko S.N., Suprunovskaya N.I., Shevchenko N.I., Monastirskiy G.E., PeretyatkoYu.V., Petruchenko O.V. Stabilization of modes of electrotechnological systems of obtaining spark-eroded micro and nano powders. Tekhnichna Electrodynamica. Tematichnyi vypusk Silova elektronika ta energoefektivnist. 2006. Vol. 1. Pp. 120-123. (Rus).

35. Zakharchenko S.N., Rudenko Yu.V. Comparative analysis of capacitors pulse charge algorithms at the systems of plasma-erosive treatment for heterogenic current-conductive mediums. Pratsi Instytutu Elektrodynamiky Natsionalnoi Akademii Nauk Ukrainy. 2014. Issue 37. Pp. 100-108. (Rus).

36. Zakharchenko S.N., Rudenko Yu.V., Cherkassky A.P. Improving the Accuracy of the Voltage Regulation in the Capacitive Energy Storage Devices for Pulse Plasma-erosion Treatment Systems of Heterogeneous Conductive Media. Tekhnichna Elektrodynamika. 2016. No 6. Pp. 30-37. (Rus). DOI:

https://doi.org/10.15407/techned2016.06.030

$\underline{\text { PDF }}$

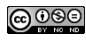

This work is licensed under a Creative Commons Attribution-NonCommercial-NoDerivatives $\underline{4.0 \text { International License }}$ 